\title{
UPAYA MENINGKATKAN HASIL BELAJAR SISWA DENGAN MENGGUNAKAN MODEL PEMBELAJARAN ARTIKULASI MATA PELAJARAN IPS DI SMP NEGERI 1 SAMBAS
}

\author{
Bohari $^{1}$, Putri Relia Anggraini ${ }^{2}$ \\ ${ }^{1,2}$ Program Studi Pendidikan Sejarah \\ Fakultas Ilmu Pendidikan dan Pengetahuan Sosial IKIP PGRI Pontianak \\ Jalan Ampera Nomor 88 Pontianak - 78116, Telepon (0561) 748219 Fax. (0561) 589855 \\ Alamat e-mail: ${ }^{1}$ bohari71ajis@gmail.com
}

\begin{abstract}
Abstrak
Penelitian ini bertujuan untuk mengetahui peningkatkan hasil belajar siswa dengan menggunakan model pembelajaran artikulasi pada mata pelajaran IPS. Penelitian tindakan kelas (classroom action research) dilaksanakan pada siswa kelas VIII G SMP Negeri 1 Sambas. Dan berdasarkan hasil analisisa data temuantemuan yang diperoleh saat penelitian tindakan dilaksanakan, maka hasil penelitiannya adalah: 1) Pelaksanaan model pembelajaran IPS di kelas VIII SMP Negeri 1 Sambas telah terlaksana dengan baik dan efektif. 2) Persentase hasil belajar siswa sebelum menggunakan model pembelajaran artikulasi dalam pembelajaran IPS di kelas VIII SMP Negeri 1 Sambas 32,36\% dinilai gagal. 3) Terdapat peningkatan hasil belajar siswa dalam pembelajaran IPS melalui model pembelajaran artikulasi yaitu pada siklus I ketuntasan klasikal yang diperoleh siswa adalah 53,38\% dalam kategori kurang, pada siklus II adalah 82,36\% berada dalam kategori baik.
\end{abstract}

Kata Kunci: hasil belajar siswa; Model Pembelajaran Artikulasi; IPS;

\begin{abstract}
This study aims to determine the improvement of student learning outcomes by using articulation learning models in social studies subjects. Classroom action research was conducted on students of class VIII G of SMP Negeri 1 Sambas. Based on the results of the data analysis of the findings obtained when the action research was carried out, the results of the study were: 1) The implementation of the social studies learning model in class VIII of SMP Negeri 1 Sambas was carried out well and effectively. 2) Percentage of student learning outcomes before using the articulation learning model in social studies learning in class VIII SMP Negeri 1 Sambas 32.36\% was considered a failure. 3) There is an increase in student learning outcomes in social studies learning through the articulation learning model in the first cycle of classical completeness obtained by students is $53.38 \%$ in the less category, in the second cycle is $82.36 \%$ are in the good category.
\end{abstract}

Keywords: student learning outcomes; Articulation Learning Model; social studies;

\section{PENDAHULUAN}

Pendidikan merupakan salah satu proses pembelajaran agar peserta didik secara aktif mengembangkan potensi dirinya menjadi lebih baik pendidikan bisa didapat dari jalur formal dan nonformal. Sekolah merupakan lembaga pendidikan yang membantu seseorang mengembangkan potensi yang dimiliki setiap individu 
melalui proses pembelajaran, sarana sumber dan tenaga kependidikan merupakan fasilitas yang membantu mendorong dan membimbing siswa dalam memperoleh keberhasilan belajar yang lebih baik.

Sekolah sebagai lembaga pendidikan membantu mengembangkan potensi yang dimiliki siswa melalui proses pembelajaran sarana sumber dan tenaga kependidikan merupakan fasilitas yang membantu mendorong dan membimbing siswa dalam pembelajaran guna memperoleh keberhasilan dalam belajar. Salah satu faktor yang juga menentukan dalam berhasil tidaknya proses pembelajaran adalah model yang digunakan oleh guru dalam menyampaikan materi pelajaran.

Belajar mengandung pengertian bahwa perubahan tingkah laku seorang akibat pengalaman yang mereka dapat melalui pengamatan, pendengaran, membaca dan meniru. Proses belajar itu juga dapat terjadi karena adanya interaksi antara seorang dengan lingkungannya. Oleh karena itu, seorang guru yang profesional harus mampu mengusai dan dapat menggunakan berbagai metode atau model mengajar. Ini sangat penting dalam proses belajar mengajar, supaya dapat meningkatkan prestasi belajar siswa.

Model pembelajaran menurut Trianto (2007:2) menyatakan "Suatu perencanaan yang dapat digunakan untuk mendesain pola-pola mengajar secara tatap muka di dalam kelas atau mengatur tutorial, dan unntuk menentukan material/perangkat pembelajaran termasuk di dalamnya buku-buku, film-film, tipetipe, program-program media komputer, dan kurikulum”. Model pembelajaran yang baik adalah model pembelajaran yang dapat menumbuhkan kegiatan dalam proses belajar siswa, serta menggunakan atau menerapkan model pembelajaran secara bervariasi. Tugas guru adalah memilih model pembelajaran yang tepat untuk menciptakan proses belajar mengajar pada pembelajran IPS.

Salah satu model pembelajaran yang dapat membantu kepentingan untuk memperbaiki diri siswa di dalam proses pembelajaran IPS adalah model artikulasi. Artikulasi merupakan pesan berantai siswa dituntut untuk dapat menyampaikan informasi kepada teman satu kelas, sesuai dengan yang dikatakan oleh (Suyatno, 2009:70) "artikulasi adalah model pembelajaran dengan sintak: penyampaian kompetensi, sajian materi, bentuk kelompok berpasangan sebangku, salah satu 
siswa menyampaikan materi yang baru diterima kepada pasangannya kemudian bergantian, presentasi di depan hasil diskusinya, guru membimbing siswa untuk menyimpulkannya". Model baru ataupun suasana yang belum pernah siswa rasakan dapat membantu siswa untuk meningkatkan hasil belajar siswa dari sebelumnya. Model ini siswa dilatih untuk berinteraksi, berkomuniikasi juga kerja sama serta siswa dilatih untuk berkompetensi dan mengingat materi pembelajaran. Sering dijumpai di dalam kelas model pembalajaran yang digunakan sangat monoton dan kejadian seperti ini cenderung membuat siswa malas, pasif selama mengikuti pembelajaran karena yang dirasa tidak menyenangkan.

Harapan dari penulisan ini adalah untuk menjelaskan bagaimana cara pengaplikasikan model pembelajaran Artikulasi di dalam proses pembelajaran sehingga nantinya memberikan dampak terhadap hasil belajar siswa. Hal ini tidak menutup kemungkinan berakibatkan pada menurunnya prestasi atau hasil belajar para siswa dan lebih jauh akan semakin menurun pula kualitas pendidikan di sekolah tersebut. Sementara hasil belajar siswa merupakan komponen yang sangat penting pada kegiatan pembelajaran dalam menentukan keberhasilan dalam proses pengajaran.

\section{METODE}

Metode yang digunakan dalam penelitian ini adalah metode penelitian tindakan kelas atau classroom action research. Supardi (2015:191) mengatakan penelitian tindakan kelas dalam bahasa inggris classroom Action Research yaitu sebuah kegiatan penelitian yang dilakukan di kelas. Penelitian tindakan kelas adalah Penelitian yang dilakukan oleh guru di dalam kelasnya sendiri dengan cara merencanakan, melaksanakan, dan merefleksikan tindakan secara kolaboratif dengan tujuan memperbaiki kinerja sebagai guru, sehingga hasil belajar siswa dapat meningkat, hal ini sesuai yang dikemukakan oleh Suhardjono (2015:124) mengemukakan bahwa:" Penelitian Tindakan Kelas adalah Penelitian Tindakan yang dilakukan oleh guru dengan tujuan memperbaiki mutu praktik pembelajaran dikelasnya".

Bentuk penelitian yang digunakan dalam penelitian ini adalah penelitian 
tindakan kolaboratif. Mahmud (2011:209) menjelaskan "bahwa penelitian tindakan kolaboratif adalah penelitian melibatkan beberapa pihak, guru, kepala sekolah, maupun dosen secara serentak meningkatkan praktik pembelajaran”. Dalam penelitian ini peneliti akan berkolaborasi dengan seorang guru IPS kelas VIII G SMP Negeri 1 Sambas. Rancangan yang digunakan dalam penelitian ini adalah penelitian tindakan kelas menggunakan model Kemmis dan McTaggart yang setiap siklusnya terdiri dari empat tahap yaitu : perencanaan (planning), tindakan (acting), pengamatan (observing), dan refleksi (reflecting). Menurut Sutrisno Hadi ( dalam Sugiyono, 2012:203) mengemukakan bahwa "Observasi merupakan suatu proses yang kompleks, suatu proses yang tersusun dari berbagai proses biologis dan psikologis. Dua diantara yang penting adalah proses-proses pengamatan dan ingatan.

Subjek

penelitiannya adalah, siswa/siswi kelas VIII G SMP Negeri 1 Sambas yang berjumlah 34 siswa, teknik data yang digunakan adalah : Teknik pengukuran Peneliti melakukan secara berstuktur, dalam hal ini peneliti membuat soal tes yang ditujukan untuk siswa/siswi kelas VIII G SMP Negeri 1 Sambas. Hasil tes kemudian dinilai dan hasil penilaian tersebut akan penulis deskripsikan sebagai salah satu hasil penelitian yang akan membantu dalam penarikan kesimpulan.

\section{HASIL DAN PEMBAHASAN}

\section{Pra Tindakan}

Pada awalnya peneliti melakukan pra tindakan hasil yang diperoleh sebelum menggunakan model pembelajaran artikulasi, hasil belajar siswa sangatlah rendah dan katagori gagal oleh karena itu peneliti berupaya menggunakan model artikulasi agar dapat meningkatan hasil belajar siswa dalam pembelajaran IPS di kelas VIII G SMP Negeri 1 Sambas. Hasil dari observasi siswa dapat disimpulkan pada dasarnya pembelajaran berjalan dengan efektif, hanya saja proses pembelajaran masih terasa pasif disebabkan dalam menggunakan model pembelajaran yang kurang variasi sehingga berdampak pada hasil belajar siswa yang masih rendah.

Sesuai dengan indikator kinerja tindakan jika hasil belajar siswa mencapai 75\% tingkat ketuntasan, maka penelitian sudah selesai dan siklus dihentikan. Untuk 
melihat indikator kinerja atau tingkat ketuntasan siswa dapat dilihat sebagai berikut, jika siswa berhasil mencapai $75 \%$ maka tingkat ketuntasan tercapai.

$$
\begin{aligned}
\text { Ketuntasan belajar } & =\frac{j u m l a ~ h \text { siswa tuntas }}{\text { jumla } h \text { semua siswa }} \times 100 \% \\
\text { Ketuntasan belajar } & =\frac{11}{34} \times 100 \% \\
& =32,36 \%
\end{aligned}
$$

Pada pra tindakan persentase hasil belajar siswa hanya 32,36 \% dari jumlah 34 siswa yang terdiri 11 siswa yang tuntas dan 23 siswa yang tidak tuntas. Rata-rata hasil belajar kelas VIII G hanya 63,38 dengan nilai tertinggi 75 dan nilai terendah 30. maka dapat disimpulkan indikator kinerjanya tidak tercapai. Hasil belajar siswa belum maksimal maka akan dilanjutkan pada siklus I.

Tabel 1. Presentase Hasil Belajar Siswa Kelas VIII G Pada Pra Tindakan

\begin{tabular}{|c|c|c|c|}
\hline NO & Hasil Belajar Siswa & Jumlah & Persentase \\
\hline 1 & Tuntas & 11 & $32,36 \%$ \\
\hline 2 & Belum Tuntas & 23 & $67,64 \%$ \\
\hline \multicolumn{2}{r|}{ Total } & 34 & 100 \\
\hline
\end{tabular}

\section{Pelaksanaan Tindakan}

\section{Siklus I}

Siklus I adalah proses pembelajaran yang pertama dilakukan dengan model Artikulasi. Proses pembelajaran yang bertujuan untuk meningkatkan hasil belajar siswa teridiri dari atas empat tahap yang dilaksanakan, yaitu: perencanaan (planning), tindakan (action), pengamatan (observer) dan refelksi (reflecting).

Kegiatan yang dilakukan pada tahap perencanaan adalah mempersiapkan rencana pelaksanaan pembelajaran (RPP) dan lembar observasi untuk mengamati proses penggunaan model pembelajaran Artikulasi di kelas VIII G SMP Negeri 1 Sambas. Setelah keperluan pelaksanaan Penelitian Tindakan Kelas, mulai dari 
materi/bahan ajar, rencana pengajaran yang mencakup model mengajar, serta instrumen observasi, dipersiapkan dengan matang pada tahap perencanaan ini.

Pada pertemuan ini guru memberikan motivasi mengenai materi yang akan diajarkan dan apa manfaatnya, serta menyampaikan tujuan pembelajaran yang mengenai materi proses persiapan kemerdekaan indonesia. Dalam menyampaikan materi pelajaran ini guru menyelipkan kegiataan tanya jawab untuk menghidupkan suasana pembelajaran, namun hanya 2 siswa yang mengajukan pertanyaan saat pembelajaran berlangsung. Setelah menjelaskan secara singkat materi tentang proses persiapan kemerdekaan indonesia, untuk mengetahui daya serap siswa guru menyiapkan model pembelajaran Artikulasi guru segera membagi siswa menjadi 17 kelompok yang masing-masing kelompok terdiri 2 siswa. Pembagian kelompok ditetapkan berdasarkan tempat duduk masing-masing. Kemudian guru menyuruh salah seorang dari pasangan untuk menceritakan materi yang baru diterima dari guru kepada pasangan kelompoknya. Dan teman kelompoknya mendengarkan penjelasan dari temannya sambil membuat catatan-catatan kecil, kemudian berganti peran. Namun pada saat siswa menjelaskan kembali materi kepada temannya masih ada yang sibuk sendiri seperti berbicara dengan temannya di luar konteks pembelajaran, Dikarenakan kurangnya ketegasan dari guru. Dari kekurangnan tersebut dapat menjadi perbaikan dipertemuan berikutnya.

Berdasarkan analisis terhadap hasil observasi kemampuan guru melaksanakan pembelajaran, pelaksanaan pembelajaran pada siklus I belum terlaksana dengan baik ditemukan sebagai berikut: bahwa guru belum bisa mengelola waktu dengan baik sehingga waktu pembelajaran melebihi waktu yang telah ditentukan dalam rencana pembelajaran. Sedangkan pengamatan terhadap hasil observasi siswa dari 34 siswa hadir semua dalam proses pembelajaran masih banyak yang tidak menyimak atau berbicara diluar konteks pembelajaran, Dilihat dari keaktifan siswa dalam kelas masih sangat kurang yaitu hanya ada 2 siswa yang bertanya pada materi yang baru di bahas.Pada saat mengerjakan soal tes, bisa dikatakan secara keseluruhan cukup baik karena pada saat mengerjakan soal tersebut hanya beberapa siswa yang masih bertanya atau melihat pekerjaan temannya. 
Tujuan dari refleksi adalah untuk mengetahui kendala sekaligus solusi pelaksanaan pada siklus berikutnya. Berdasarkan hasil pengamatan selama proses pembelajaran menunjukan bahwa penggunaa model pembelajaran artikulasi di kelas VIII G SMP Negeri 1 Sambas belum sepenuhnya tampak. Meskipun sudah dijelaskan, masih terdapat beberapa siswa yang belum mengerti dengan penggunaan model pembelajaran Artikulasi di kelas VIII G Sambas serta nilai tes menujukan presentase pencapaian hasil yang belum maksimal. Oleh karena itu, peneliti dan kolaborator berkesimpulan bahwa indikator pelaksanaan penelitian belum tercapai dikarenakan belum mencapai hasil belajar yang telah ditentukan yaitu presentase hasil belajar yang ingin dicapai sebesar $75 \%$ dari jumlah siswa yang diteliti dan sepakat melanjutkan ke siklus II untuk memperbaiki tindakan yang belum terlaksana pada siklus I.

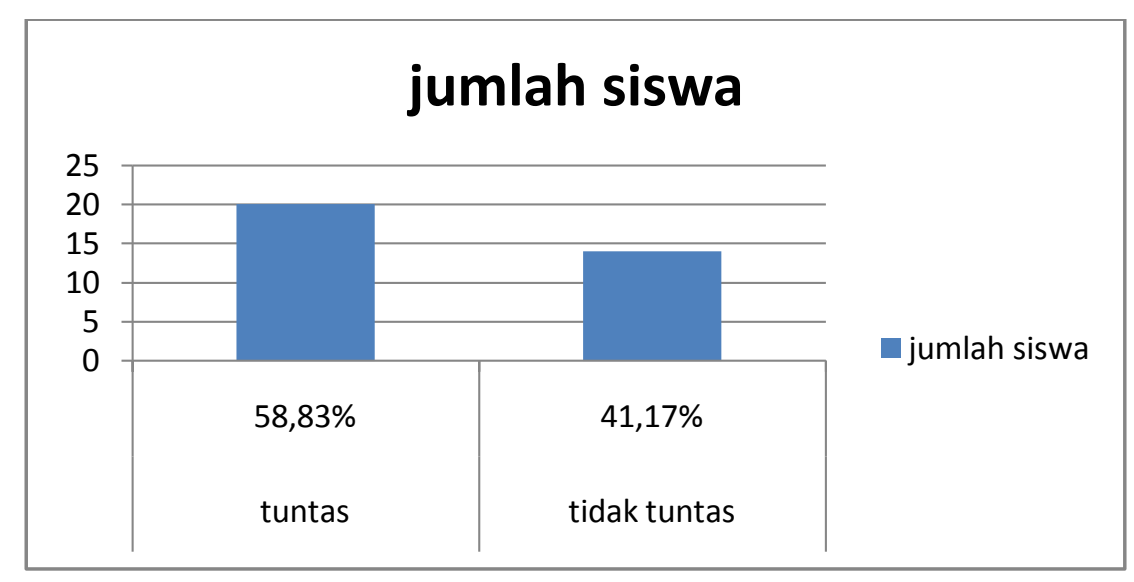

Gambar 1. Grafik Hasil Belajar Siswa Siklus I

\section{Siklus 2}

Siklus 2 dilaksanakan berdasarkan hasil refleksi pembelajaran disiklus I yang belum bisa dikatakan berhasil. Lanjut tindakan siklus II ini mempunyai tahap yang sama dengan tindakan siklus I yang meliputi tahapan perencanaan (planning), pelaksanaan (acting), observasi (observing), dan refleksi (reflekting), yang bertujuan untuk memperbaiki hasil belajar siswa.

Berdasarkan hasil refleksi pelaksanaan tindakan siklus I diketahui bahwa hasil belajar siswa pada pembelajaran IPS di kelas VIII G SMP Negeri 1 Sambas 
telah mengalami peningkatan dari kondisi awal sebelum dilaksanakan siklus I, tetapi penggunaan model pembelajaran Artikulasi di kelas VIII G SMP Negeri 1 Sambas belum maksimal. Hal ini ditunjukan dengan ketuntasan belajar siswa sebesar 58,83\% dengan rata-rata kelasnya adalah 67,05. Berdasarkan hasil pengamatan dan hasil belajar siswa maka peneliti dan guru berdiskusi untuk melakukan kegiatan perbaikan pada siklus II.

Dalam tahap perencanaan mempersiapkan segala perangkat yang dibutuhkan dalam pelaksanaan tindakan penelitian, yaitu berupa rancangan pembelajaran dengan menggunakan model artikulasi yaitu panduan observasi aktifitas guru dan siswa, perangkat pembelajaran yang disiapkan yaitu RPP dan lembar soal tes. Proses pembelajaran pada siklus II lebih ditekankan kepada siswa agar lebih fokus mendengarkan penjelasan materi yang disampaikan oleh guru, hal ini bertujuan guna kelancaran pada saat pelaksanaan tindakan.

Pelaksanaan siklus II dilaksanakan dengan jumlah siswa sebanyak 34 orang yang mengikuti proses pembelajaran. Sebelum memasuki kelas guru mempersiapan prangkat pembelajaran yang digunakan berupa sumber belajar, silabus dan RPP yaitu sesuai dengan materi pelajaran. Penelitian tindakan pada siklus II menggunakan model pembelajaran artikulasi sebagai model pembelajaran. Pelaksanaan siklus II ini dirancang agar kesalahan serta kekurangan yang terjadi pada siklus I bisa diperbaiki. Materi disesuaikan dengan RPP dan pemanfaatan waktu lebih efektif dari sebelumnya pada siklus I. Pertemuan pertama Guru kolaborator sebagai pelaksana tindakan dan peneliti sebagai observer memasuki ruang kelas VIII G kemudian diawali dengan mengucapkan salam dan salah satu siswa menyiapkan kelas. Setelah itu guru mengelola kelas dengan memberi semangat kepada siswa agar mempersiapkan kondisi kelas sebelum menerima pelajaran dengan meminta merapikan tempat duduk. Kemudian guru menyapa siswa dilanjutkan guru melakukan mengabsen siswa serta memberikan motivasi mengenai materi yang akan diajarkan. Guru melanjutkan dengan menyampaikan kompetensi dari materi yang akan dibahas kepada siswa serta menjelaskan materi pelajaran mengenai pembentukan PPKI. Dalam menyampaikan materi pelajaran ini guru menyelipkan kegiatan tanya jawab untuk menghidupkan suasana 
pembelajaran. Siswa yang mengajukan pertanyaan lebih meningkat dibandingkan dengan siklus I. Guru segera membagi siswa dalam kelompok, pembagian kelompok ditetapkan oleh guru berdasarkan kelompok pada siklus I.

Selanjutnya, guru mengarahkan salah seorang dari pasangan untuk menceritakan kembali materi yang baru diterima dari guru. Dan teman kelompoknya mendengarkan penjelasan dari temannya sambil membuat catatancatatan kecil. Siswa berganti peran sesuai kelompoknya. Setelah selesai salah satu siswa sebagai perwakilan kelompok memaparkan hasil diskusinya di depan kelas. Pendalaman materi dilakukan guru waktu siswa menyampaikan hasil diskusi di depan kelas.

Penerapan model artikulasi digunakan untuk mengetahui tingkat pemahaman siswa terhadap materi yang telah disampaikan dengan bekerja dalam kelompok. Sedangkan untuk mengetahui perkembangan pengetahuan siswa dengan memberikan tes berbentuk esay berjumlah 5 soal pada siklus II.

Observasi ini dilakukan selama berlangsungnya kegiatan pembelajaran pada siklus II. Peneliti masih melakukan observasi dengan menggunakan alat yang sama pada siklus I yaitu panduan observasi guru ini disusun dalam bentuk checklist $(\sqrt{ })$ sedangkan lembar soal tes disusun dalam bentuk pilihan esay yang komponen komponenanya terdapat di dalam rencana pembelajaran. Proses pembelajaran sebagai pelaksana tindakan mengajar mata pelajaran IPS. Dalam hal ini proses pembelajaran menggunakan model pembelajaran artikulasi.

Berdasarkan komponen-komponen yang terdapat dalam wacana rencana pengajaran, lembar observasi digunakan untuk mengamati proses pembelajaran di kelas dan untuk melihat hasil belajar siswa dalam pembelajaran. Sedangkan dalam lembar observasi guru menunjukan bahwa pada proses pembelajaran siklus II meningkat dibanding siklus I.

Adapun hasil pengamatan yang telah dilakukan oleh observer pada panduan observasi melihat dari 34 siswa yang hadir dalam pembelajaran, aktivitas siswa mengalami peningkatan yaitu siswa lebih fokus terhadap penjelasan guru, siswa turut aktif dalam bertanya pada guru. Siswa lebih bersemangat dan peduli terhadap model artikulasi, karena siswa dilibatkan dalam pembelajaran. 
Seperti pada siklus I, pada akhir siklus II juga diadakan refleksi terhadap pelaksanaan proses pembelajaran. Proses pembelajaran siklus II dengan menggunakan model pembelejaran artikulasi mengalami penigkatan sesuai dengan yang diharapkan, siswa yang mencapai ketuntasan belajar mencapai 82,38\% sehingga telah melebihi standar ketuntasan yang ada. hasil ini menunjukan bahwa pelaksanaan siklus II dinilai sudah berhasil. Dengan demikian penelitian hanya sampai pada siklus II saja.

Sesuai dengan kriteria ketuntasan minimal yakni 72 dan indikator kinerja yang ditetapkan, maka pada tabel hasil tes siklus dapat disimpulkan bahwa jumlah siswa yang mendapatkan nilai 72 ke atas atau di atas KKM berjumlah 28 siswa, dan yang mendapatkan nilai di bawah KKM berjumlah 6 siswa dari jumlah secara keseluruhan yaitu 34 siswa dengan nilai rata-rata 75,58 dan nilai tertinggi 85 dan nilai terendah 60. Sedangkan untuk melihat indikator kinerja tindakan atau ketuntasan klasikal siswa dapat dilihat di bawah ini :

$$
\begin{aligned}
\text { Ketuntasan Belajar } & =\frac{\text { Jumlah Siswa Tuntas }}{\text { Jumlah Semua Siswa }} \times 100 \% \\
\text { Ketuntasan Belajar } & =\frac{28}{34} \times 100 \% \\
\text { Jadi, ketuntasan Belajar } & =82,36 \%
\end{aligned}
$$

Ketuntasan Klasikal mencapai 82,36\%. maka dapat disimpulkan ketuntasan klasikal atau indikator kinerja tercapai sesuai dengan kriteria penilaian SMP Negeri 1 Sambas pada hasil belajar mata pelajaran IPS kelas VIII G sudah mencapai melebihi $75 \%$ (kriteria ketuntasan klasikal) maka penelitian hanya sampai pada siklus II.

Tabel 2. Presentase Hasil Belajar Siswa Pada Siklus II

\begin{tabular}{|c|c|c|c|}
\hline NO & Hasil Belajar Siswa & Jumlah & Preesentase \\
\hline 1 & Tuntas & 28 & $82,36 \%$ \\
\hline 2 & Tidak Tuntas & 6 & $17,64 \%$ \\
\hline \multicolumn{2}{|c|}{ Total } & 34 & 100 \\
\hline
\end{tabular}


Untuk lebih jelas dalam mendapatkan gambaran hasil belajar siswa pada siklus II dapat dilihat tabel atas dan dapat dilihat grafik 2 dapat dilihat penjabaran dari data yang telah dianalisa oleh peneliti.

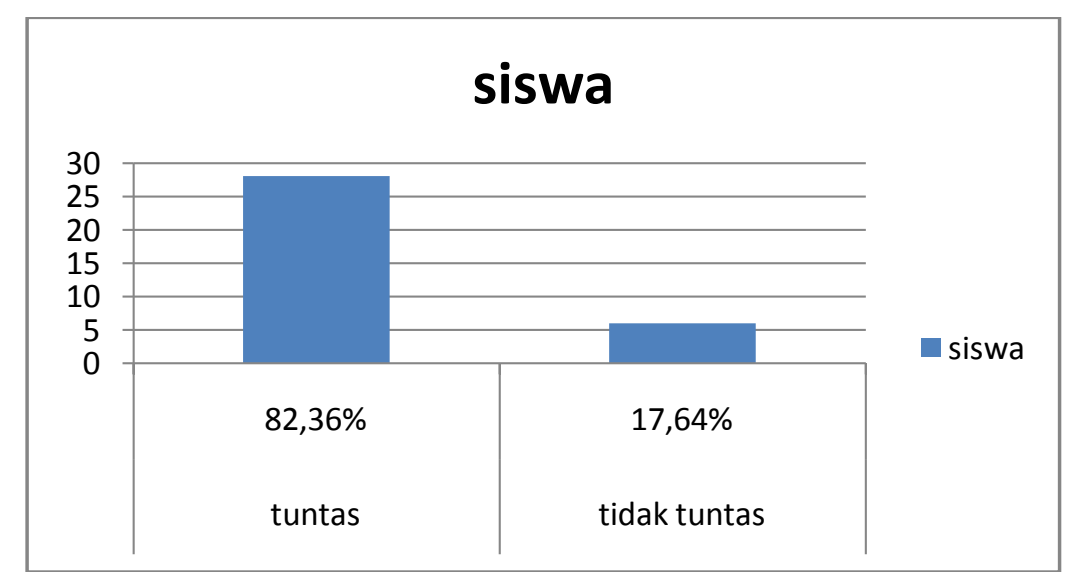

\section{Gambar 2. Grafik Hasil Belajar Siswa Siklus II}

Secara umum, berdasarkan hasil penelitian yang dilakukan di kelas VIII G SMP Negeri 1 Sambas menunjukan pelaksanaan pembelajaran IPS dengan menggunakan model artikulasi yang diterapkan oleh guru dikata gorikan baik., siswa belajar efektif, siswa menjadi aktif dan siswa menjadi termotivasi dalam proses pembelajaran. Dari observasi yang dilakukan menemukan suasana belajar melalui model pembelajaran Artikulasi mengalami peningkatan dibandingkan sebelum dilaksanakan model artikulasi.

Berdasarkan hasil penilaian belajar siswa kelas VIII G SMP Negeri 1 Sambas menunjukan hasil belajar siswa pada pra tindakan terdapat 11 siswa yang tuntas sedangkan yang tidak tuntas 23 siswa nilai tertinggi 75 dan terendah 30 dengan nilai rata-rata 63,38 dengan ketutasan klasikal 32,36\% sedangkan siklus I terdapat 20 siswa yang tuntas dan tidak tuntas 19 siswa, nilai tertinggi 95 dan yang terendah adalah 25 dengan nilai rata-rata 67,05 dan ketuntasan klasikal 58,83\%. Sedangkan pada siklus II adalah terdapat 28 siswa yang tuntas dan 6 siwa yang tidak tuntas, dengan nilai tertinggi 85 dan nilai terendah 60 nilai rata-rata 75,58 dengan ketuntasan klasikal 82,36\%. Berdasarkan penjelasan di atas, dapat dilihat bahwa terjadi peningkatan hasil belajar siswa. Untuk mengetahui grafik dari siklus I dan siklus II terlihat peningkatan antara siklus I ke siklus II sebesar 23,53\%. 


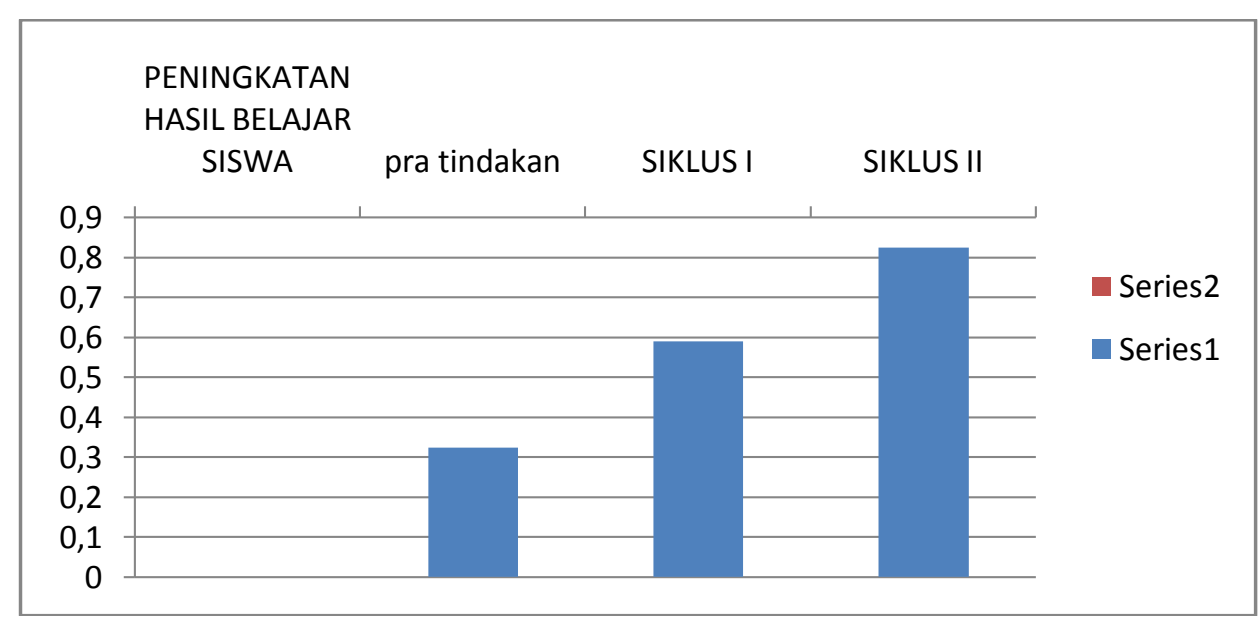

Gambar 3. Grafik Peningkatan Hasil Belajar Siswa

Penelitian tindakan kelas dapat dikatakan berhasil, dilihat dari grafik di atas terdapat peningkatan hasil belajar baik dari nilai rat-rata kelas, maupun hasil belajar siswa secara individu dan klasikal. Dengan demikian penerapan model pembelajaran artikulasi dapat meningkatkan hasil belajar Ilmu Pengetahuan Sosial di kelas VIII G Sekolah Menengah Pertama Negeri 1 Sambas.

\section{SIMPULAN}

Berdasarkan hasil penelitian dan pembahasan yang diperoleh dalam proses pembelajaran yang telah dilakukan maka secara umum dapat disimpulkan bahwa melalui model pembelajaran Artikulasi mampu meningkatkan hasil belajar siswa dalam pembelajaran IPS kelas VIII G SMP Negeri 1 Sambas. Secara khusus dapat di tarik kesimpulan sebagai berikut:

1. Pelaksanaan model pembelajaran artikulasi dalam pembelajaran IPS di kelas VIII G SMP Negeri 1 Sambas telah terlaksana dengan baik dan efektif, sesuai dengan perencanaan, tindakan, pengamatan, dan refleksi yang telah ditentukan.

2. Hasil belajar siswa sebelum menggunakan model pembelajaran Artikulasi dalam pembelajaran IPS dikelas VIII G SMP Negeri 1 Sambas persentase hasil belajar siswa 32,36\% dinilai gagal, hal ini dapat dilihat dari pra tindakan yang peneliti lakukan. Hasil belajar siswa sebelum menggunakan model pembelajaran artikulasi sebagian besar hasil belajar siswa masih gagal, siswa masih cenderung pasif, sibuk aktivitas sendiri dalam proses pembelajaran. 
Terdapat peningkatan hasil belajar siswa dalam pembelajaran IPS melalui model pembelajaran artikulasi pada siswa kelas VIII G SMP Negeri 1 sambas. Dapat diketahui setelah membandingkan tes hasil belajar dari siklus I dan siklus II. Pada siklus I ketuntasan klasikal yang diperoleh siswa adalah 53,83\% dalam kategori kurang. Pada siklus II adalah 82,36 \% atau berada dalam kategori baik. Bearti dari pra tindakan ke siklus I naik terjadi kenaikan menjadi 26,47\% sedangkan pada siklus II naik menjadi 28,53\%. Hal tersebut menunjukan bahwa hasil belajar siswa kelas VIII G SMP Negeri Sambas setelah menggunakan model artikulasi mengalami peningkatan.

\section{DAFTAR PUSTAKA}

Mahmud. 2011. Metode Penelitian Pendidikan. Bandung: CV Pustaka Setia.

Suhardjono. 2015. Penelitian Tindakan Kelas. Jakarta: Bumi Aksara.

Sugiyono. 2012. Metode Penelitian Pendidikan. Bandung: Alfabeta.

Suyatno. 2009. Menjelajah Pembelajaran Inovatif. Jawa Timur: Buana Pustaka.

Supardi. 2015. Penelitian Tindakan Kelas. Jakarta: Bumi Aksara.

Trianto. 2007. Model Pembelajaran Terpadu Dalam Teori dan Praktek. Jakarta: Prestasi Pustaka. 